\title{
Fresh perspectives for classic forest restoration challenges
}

\author{
Asun Rodríguez-Uña ${ }^{1,2}$, Verónica Cruz-Alonso ${ }^{3}$, Zoë Rohrer ${ }^{3}$, Loreto Martínez-Baroja ${ }^{3}$ \\ ${ }^{1}$ Basque Centre for Climate Change (BC3), Edif. Sede 1, 1․ Parque Científico UPV. \\ 48940 Leioa, Spain. \\ 2 Department of Plant Biology and Ecology, Faculty of Science and Technology, \\ University of the Basque Country, Barrio Sarriena s/n, 48940 Leioa, Spain. \\ ${ }^{3}$ Forest Ecology and Restoration Group, Departamento de Ciencias de la Vida, \\ Universidad de Alcalá, 28805 Alcalá de Henares, Madrid, Spain.
}

\section{Corresponding author: Asun Rodríguez-Uña}

Email: asun.rodriguez@bc3research.org

\section{Author contributions}

ARU, VCA, ZR, LMB conceived the idea, and wrote and reviewed the manuscript.

Running head: Forest restoration challenges

Keywords: ecosystem recovery; restoration assessment; restoration planning; restoration success

\section{Implications for practice}

- Recognizing and solving classic issues in ecological restoration is crucial for this developing science to continue being applicable under the current fast changing environmental conditions.

- Young restoration scientists' voices may shed fresh views on classical problems and help to achieve future international commitments.

This article has been accepted for publication and undergone full peer review but has not been through the copyediting, typesetting, pagination and proofreading process which may lead to differences between this version and the Version of Record. Please cite this article as doi: $10.1111 /$ rec.13093 
- Anticipating restoration, using multiple references and indicators that reflect ecosystem complexity, and promoting academia-practitioner partnerships in restoration projects, are feasible approaches already applied by young restoration ecologists to face classic restoration challenges.

\begin{abstract}
Restoration ecology is a young scientific discipline with limitations that compromise the recovery of ecosystem biodiversity and functions. Specifically for forest restoration planning and assessment, we first recommend measures prior to land use changes to deal with the common lack of efforts to anticipate and plan restoration. Second, we suggest using multiple references in restoration planning to avoid simplified reference characterization. Further, we advise assessing ecosystem recovery with indicators that better incorporate ecosystem complexity in recovery assessments. Finally, we propose initiatives to encourage scientific communication outside academia to diminish the communication gap between scientists and practitioners.
\end{abstract}

\title{
Introduction
}

Ecological restoration is today a key tool to counteract the global increase of ecosystem degradation and biodiversity loss (Aronson \& Alexander 2013; Bastin et al. 2019), as has been acknowledged by the declaration of 2021-2030 as the United Nations Decade of Ecosystem Restoration (UN 2019). However, restoration ecology is a young discipline, which still faces challenges that need to be urgently addressed (Buisson et al. 2018). Restoration planning and assessment are essential stages of ecological restoration (Figure 1). Both stages are frequently discussed in scientific literature (Higgs et al. 2014), especially in forests (where restoration actions have been traditionally accomplished), 
showing that they can compromise forest restoration success (Vallauri et al. 2005; Gatica-Saavedra et al. 2017). Here we focus on four challenges for forest restoration planning and assessment which we have encountered as young researchers, and suggest a fresh perspective to overcome these constraints. As young restoration ecologists, we must assume our share of responsibility to the challenges of ecological restoration in a changing world.

\section{Challenge 1: Land use management to anticipate restoration}

Planning land use (i.e., exploitation and land use changes) is crucial to reducing degradation of prior uses and costs of subsequent forest restoration (Rey Benayas et al. 2016; Rohrer et al. 2018). Despite having the knowledge and tools to anticipate restoration, planned actions are often not implemented due to ecological and socioeconomic reasons. Regarding the first, understanding ecosystems, their components and the interactions between organisms is complex (e.g., seed dispersal, Pesendorfer et al. (2016)). Among the socio-economic reasons, traditional agriculture is usually focused on provisioning services, restricting or eliminating natural vegetation, like perimetral hedgerows (Rey Benayas et al. 2008, Van Vooren et al. 2017).

During the active farming phases, implementing actions, such as planting hedgerows and isolated trees, can maintain seed sources, increase biodiversity, and provide habitats for animals (Manning et al. 2006; Rey Benayas et al. 2008). When degradation is caused by mining operations, actions like maintaining vertical faces can promote rocky habitats for rupicolous vegetation. Incorporating restoration actions during the exploitation may help to accelerate colonization and succession, and maintain rupicolous plant species (Rohrer et al. 2019). These actions may improve ecosystem services 
during the active land use phase (e.g., pest control) and could shorten the time needed for the ecosystem to recover after land use change (e.g., seed dispersal), reducing restoration costs and catalyzing restoration process (Pesendorfer et al. 2016; Andivia et al. 2017). Consequently, despite the ecological and economic limitations, the implementation of planned actions could favor restoration success.

\section{Challenge 2: Reference ecosystem identification}

The use of references (i.e., models of the ecosystem condition prior to degradation; McDonald et al. 2018) for designing the restoration of degraded sites may be controversial (Dufour \& Piégay 2009; Aronson et al. 2017). First, the inherent uniqueness of each reference and degraded site (i.e., its biotic and abiotic legacies) implies that no reference is a perfect match for a given degraded site (White \& Walker 1997). Moreover, the characterization of references can be costly and time consuming in practice, and it is usually simplified (i.e., by using few reference sites; Ruiz-Jaen \& Mitchell Aide (2005)).

The problem of site specificity could be partially solved by using multiple references for each restored site, selected within a range of similar environmental conditions (White \& Walker 1997). Therefore, a range of variation of reference values could be incorporated in restoration design. Cruz-Alonso et al. (2019) identified all possible refer ence forests using the Spanish Forest Inventory - an open access database of gridded forest plots (Alberdi et al. 2016) -, selecting those closer than $15 \mathrm{~km}$ and $200 \mathrm{~m}$ in altitude from the restored forest and within the same forest type. The use of already existing public biotic and abiotic databases to characterize different ecosystem attributes (e.g., land cover maps, historical aerial photographs; Ruiz-Benito et al. Under review) may reduce the cost of using multiple references. To date, this systematic information is not available for forests in most parts of the world, but there is a worldwide trend of sharing biodiversity 
data (García 2019). The use of multiple references characterized through biodiversity databases could help restoration design in the near future.

\section{Challenge 3: Indicator selection and long-term recovery}

Over the last few years, several studies have concluded that most restored forest ecosystems do not recover the biodiversity and functions that existed prior to disturbance (e. g., Curran et al. 2014; Moreno-Mateos et al. 2017). However, the assessment of ecosystem recovery is usually based on simplified metrics that do not capture the complexity of the ecosystem (e.g., number of species), and that are only measured for a few years after restoration takes place (Ruiz-Jaen \& Mitchell Aide 2005; Montoya et al. 2012). This may lead to an underestimation of the actual time required for ecosystems to recover.

Long-term monitoring may be unrealistic for practitioners and scientists. A chronosequence-based approach (i.e., space-for-time substitution) might be a feasible alternative for scientists to explore ecosystem recovery in the long-term (Sutherland et al. 2016; Cruz-Alonso etal. 2019). This method requires the disturbance cessation date, but records are often not available, thus, using dating techniques becomes necessary. For example, to date the abandonment of ancient mines later covered by a beech forest, several techniques can be used: i) consulting local history records; ii) using optically stimulated luminescence to determine when sediments rich in silica were last exposed to sun radiation; iii) using dendrocronological approaches to estimate the beginning of tree recruitment after perturbation.

Alternative approaches with metrics integrating higher complexity (e.g. interaction networks and multifunctionality indexes (Cruz-Alonso et al. 2019; Rodríguez -Uña et al. 
2019)) and for longer time periods should be applied, as many ecosystems may need centuries or more to fully recover (Curran et al. 2014; Rey Benayas et al. 2015).

\section{Challenge 4: The communication between science and practice}

Restoration ecologists develop new knowledge, but what is studied is not always focused on what needs to be developed in practice, and scientists frequently lack experience or opportunities to carry out applied programs (Hopkinson et al. 2017). Furthermore, they do not have easy access to knowledge produced outside academia. On the other hand, most practitioners have limited access to scientific information, such as scientific journals (Amano et al. 2016). Moreover, their perspectives are not always aligned with the theoretical models for ecological restoration (Aronson et al. 2017) and finally, businessas-usual approaches, such as monospecific and linear revegetation, seem hard to abandon.

To overcome these issues, effective academia-practitioner collaboration and sharing information is essential (Meli et al. 2019). Collaborations would enable scientists to test their knowledge (Castillo 2000) and help practitioners to improve practices toward making scientific based decisions. For example, through an innovative partnership with the University of Castilla-La Mancha, the mining company LafargeHolcim Spain is restoring natural vegetation at a quarry, based on the university's studies on secondary succession (Usarek et al. 2018). The mining company has partnerships with other organizations as well, such as non-profit NGOs like the FIRE Foundation (Rohrer 2019). Furthermore, scientists could provide the knowledge to Administrations so they can include ecological requirements in their restoration programs, thus encouraging practitioners to prioritize these practices in their project planning and design. 
Finally, in the current competitive and publishing driven environment in science (Mazón et al. 2019), scientists should be rewarded for communicating their findings outside of academia (Castillo 2000), e.g. by assigning specific scores for scientific dissemination when applying for official scholar quality assessments and accreditations such as the ANECA in Spain (ANECA 2019), or when applying for project funding. Efforts towards finding common working grounds and sharing knowledge is crucial to achieving ecological restoration goals.

\section{Conclusion}

In the coming decades, young restoration ecologists will continue to face old problems in a rapidly changing environment, and they will play an essential role in developing ecological restoration as a useful tool to revert ecosystem degradation. Here we propose fresh approaches to overcome some of the main challenges in forest restoration planning and assessment. First, we call for planning measures prior to land use changes to facilitate restoration. Then, we recommend the use of multiple references when planning ecological restoration and the use of indicators integrating forest complexity to assess long-term recovery. Finally, we address how to reduce the science-practice communication gap by promoting knowledge dissemination outside academia. All of these proposals could be integrated to better accomplish international forest restoration initiatives.

\section{Acknowledgements}

We appreciate the early revision of the manuscript by Paloma Ruiz-Benito, Enrique Andivia and David Moreno-Mateos. We also thank David Rohrer for reviewing the English. ARU was funded by Environmental Fellowship Programme of "Tatiana Pérez 
de Guzmán el Bueno" Foundation (2016) and María de Maeztu excellence accreditation (MDM-2017-0714) from the Spanish Government, VCA by REMEDINAL4 (Madrid Government, TE-CM S2018/EMT-4338), ZR by the LafargeHolcim, FIRE Foundation and UAH partnership and LMB by the FPI fellowship (BES-2015-075276) from the Spanish Government.

\section{Literature}

Alberdi I, Sandoval V, Condes S, Canellas I, Vallejo R (2016) The Spanish National Forest Inventory, a tool for the knowledge, management and conservation of forest ecosystems. Ecosistemas 25:88-97

Amano T, González-Varo JP, Sutherland WJ (2016) Languages are still a major barrier to global science. PLOS Biology 14:e2000933

Andivia E, Villar-Sa Ivador P, Tovar L, Rabasa S, Rey Benayas JM (2017) Multiscale assessment of woody species recruitment in Mediterranean shrublands: facilitation and beyond. Journal of Vegetation Science 28:639-648

ANECA (National Agency for Quality Assessment and Accreditation of Spain) (2019) http://www.aneca.es/

Aronson J, Alexander S (2013) Ecosystem restoration is now a global priority: time to roll up our sleeves. Restoration Ecology 21:293-296

Aronson J, Blignaut JN, Aronson TB (2017) Conceptual frameworks and references for landscape-scale restoration: Reflecting back and looking forward. Annals of the Missouri Botanical Garden 102:188-200

Bastin JF, Finegold Y, Garcia C, Mollicone D, Rezende M, Routh D, Zohner CM, 
Crowther TW (2019) The global tree restoration potential. Science 365:76-79

Buisson E, Jaunatre R, Regnery B, Lucas M, Alignan JF, Heckenroth A, Muller I et al. (2018) Promoting ecological restoration in France: issues and solutions. Restoration Ecology 26:36-44

Castillo A (2000) Communication and utilization of science in developing countries: The case of Mexican ecology. Science Communication 22:46-72

Cruz-Alonso V, Ruiz-Benito P, Villar- Salvador P, Rey- Benayas JM (2019) Long -term recovery of multifunctionality in Mediterranean forests depends on restoration strategy and forest type. Journal of Applied Ecology 56:745-757

Curran M, Hellweg S, Beck J (2014) Is there any empirical support for biodiversity offset policy? Ecological Applications 24:617-632

Dufour S, Piégay H (2009) From the myth of a lost paradise to targeted river restoration: forget natural references and focus on human benefits. River Research and Applications 25:568-581

García C (2019) From ecological indicators to ecological functioning: Integrative approaches to seize on ecological, climatic and socio-economic databases. Ecological Indicators 107:105612

Gatica-Saavedra P, Echeverría C, Nelson CR (2017) Ecological indicators for assessing ecological success of forest restoration: a world review: Indicators for forest restoration. Restoration Ecology 25:850-857

Higgs E, Falk DA, Guerrini A, Hall M, Harris J, Hobbs RJ, Jackson ST, Rhemtulla JM, Throop W (2014) The changing role of history in restoration ecology. Frontiers 
in Ecology and the Environment 12:499-506

Hopkinson P, Huber A, Saah DS, Battles JJ (2017) A Word to the Wise: Advice for Scientists Engaged in Collaborative Adaptive Management. Environmental Management 59:752-761

Manning AD, Fischer J, Lindenmayer DB (2006) Scattered trees are keystone structures - Implications for conservation. Biological Conservation 132:311-321

Mazón M, Aguirre N, Echeverría C, Aronson J (2019) Monitoring attributes for ecological restoration in Latin America and the Caribbean region. Restoration Ecology 27:992-999

McDonald T, Gann G, Jonson J, Dixon K (2018) International standards for the practice of ecological restoration - Including principles and key concepts. Society for Ecological Restoration, Washington, D.C.

Meli P, Schweizer D, Brancalion PH, Murcia C, Guariguata MR (2019) Multidimensional training among Latin America's restoration professionals. Restoration Ecology 27:477-484

Montoya D, Rogers L, Memmott J (2012) Emerging perspectives in the restoration of biodiversity-based ecosystem services. Trends in Ecology \& Evolution 27:666672

Moreno-Mateos D, Barbier EB, Jones PC, Jones HP, Aronson J, López-López JA et al. (2017) Anthropogenic ecosystem disturbance and the recovery debt. Nature Communications 8:14163

Pesendorfer MB, Sillett TS, Koenig WD, Morrison SA (2016) Scatter-hoarding corvids 
as seed dispersers for oaks and pines: a review of a widely distributed mutualism and its utility to habitat restoration. The Condor 118:215-237

Rey Benayas JM, Bullock JM, Newton AC (2008) Creating woodland islets to reconcile ecological restoration, conservation, and agricultural land use. Frontiers in Ecology and the Environment 6:329-336

Rey Benayas JM, Gómez Crespo J-I, Mesa Fraile AV (2016) Guía para la plantación de setos e islotes forestales en campos agrícolas mediterráneos. Fundación Internacional para la Restauración de Ecosistemas, Madrid. https://www.fundacionfire.org/images/pdf/guia\%20restauracion md.pdf

Rey Benayas JM, Martínez-Baroja L, Pérez-Camacho L, Villar-Salvador P, Holl KD (2015) Predation and aridity slow down the spread of 21-year-old planted woodland islets in restored Mediterranean farmland. New Forests 46:841-853

Rodríguez-Uña A, Hidalgo-Castañeda J, Salcedo I, Moreno-Mateos D (2019) Recuperación de las interacciones entre el haya (Fagus sylvatica) y los hongos ectomicorrícicos 140 años después del fin de la actividad minera. Ecosistemas 28:61-68

Rohrer Z (2019) Breeding cliff-nesting birds at mining sites: Management recommendations. PhD Dissertation, Universidad de Alcalá, Alcalá de Henares, Spain

Rohrer Z, Rebollo S, Andivia E, Rodríguez C, Franco J (2019) Bird services applicable to mine restoration: a case study of Sand Martin (Riparia riparia) burrow construction. Journal of Ornithology

Rohrer Z, Rebollo S, Gegúndez P (2018) Guía de buenas prácticas para el avión 
zapador en explotaciones de áridos. LafargeHolcim, FIRE \& UAH. Madrid, Spain.

https://www.researchgate.net/publication/328430344 Guia de buenas practic as para el avion zapador en explotaciones de aridos

Ruiz-Benito P, Vacchiano G, Lines ER, Reyer CPO, Ratcliffe, S, Morin, X et al. (2020) Available and missing data to model impact of climate change on European forests. Ecological Modelling

Ruiz-Jaen MC, Mitchell Aide T (2005) Restoration Success: How Is It Being Measured? Restoration Ecology 13:569-577

Sutherland IJ, Bennett EM, Gergel SE (2016) Recovery trends for multiple ecosystem services reveal non-linear responses and long-term tradeoffs from temperate forest harvesting. Forest Ecology and Management 374:61-70

UN (United Nations) (2019) https://undocs.org/es/A/RES/73/284

Usarek E, Isabel JM, Sardinero S (2018) Ecological restoration of a limestone quarry in central Spain, from Science to Practice. Quarries Alive 2018 - Enhancing Biodiversity and Ecosystems Services in Quarries - Challenges, Strategies and Practice. Évora 2-4 May 2018. Universidade de Évora, Portugal.

Vallauri D, Aronson J, Dudley N (2005) An Attempt to Develop a Framework for Restoration Planning. In: Forest Restoration in Landscapes. Springer-Verlag, New York pp. 65-70.

Van Vooren L, Reubens B, Broekx S, De Frenne P, Nelissen V, Pardon P, Verheyen K (2017) Ecosystem service delivery of agri-environment measures: A synthesis for hedgerows and grass strips on arable land. Agriculture, Ecosystems \& 
Environment 244:32-51

White PS, Walker JL (1997) Approximating Nature's Variation: Selecting and Using Reference Information in Restoration Ecology. Restoration Ecology 5:338-349 


\section{Figure caption}

Figure 1. Stages of ecological restoration (from the exploitation of resources to the restored ecosystem) based on McDonald et al. (2018) (green dotted square). The loop of the arrow represents the adaptive management approach where the monitoring and the maintenance stages repeat as often as necessary to obtain the restored ecosystem. The tips below each stage are discussed in this article.

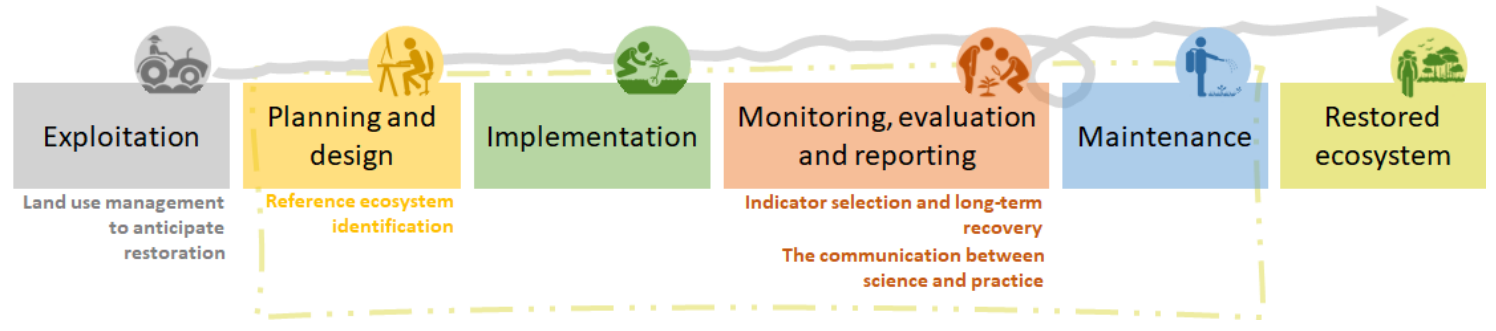

